\title{
置土された土砂の流下過程の 数値解析モデルの構築と実河川における適用 DEVELOPMENT OF NUMERICAL MODEL ON TRANSPORT PROCESS OF REPLENISHED SEDIMENT AND ITS APPLICATION
}

\author{
武藏 由育 1 ・志宇知 誠 2 - 山下 正浩 3 ・竹林 洋史 4
}

湯城 豊勝 5 ・鎌田 磨人 6 ・赤松 良久 7 ・河口 洋一 8 ・ 中田 泰輔 9

Yoshiiku MUSASHI, Makoto SHIUCHI, Masahiro YAMASHITA, Hiroshi TAKEBAYASHI, Toyokatsu YUKI, Mahito KAMATA, Yoshihisa AKAMATSU, Yoichi KAWAGUCHI and Yasusuke NAKATA

\author{
1正会員 農修 八千代エンジニヤリング株式会社 水工部（†161-8575 東京都新宿区西落合2-18-12） \\ 2 非会員 工 国土交通省 那賀川河川事務所 管理課（干774-0011 阿南市領家町室/内390) \\ 3 正会員 国土交通省 那賀川河川事務所 調查·品質確保課（率774-0011 阿南市領家町室八内390） \\ 4 正会員 博士 (工学) 京都大学准教授 防災研究所 ( $612-8235$ 京都市伏見区横大路下三栖東ノ口) \\ 5 正会員 博士 (工学) 阿南工業高等専門学校教授 建設システム工学科 (下774-0017 阿南市見能林町青木265) \\ 6 正会員 学博 徳島大学教授 工学部建設工学科（率770-8506 徳島市南常三島町2-1)

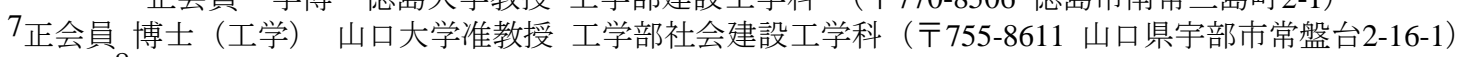 \\ 8 正会員 学博 徳島大学准教授 工学部建設工学科（T770-8506 徳島市南常三島町2-1） \\ 9 正会員 工修八千代エンジニヤリング株式会社 環境計画部（テ161-8575 東京都新宿区西落合2-18-12）
}

As a method of countermeasure to bed degradation and armoring phenomena of bed material in the downstream are of dam reservoirs, sediment augmentation has been carried out in many Japanese rivers. However, the effect of sediment augmentation on the bed elevation, sediment size and habitat in the downstream reach of the sediment augmentation has not been studied well because of the small amount of the replenished sediment. In this study, one dimensional bed deformation analysis is developed to simulate the sediment transport process of the replenished sediment in the Nakagawa, Tokushima. Here, the Japanese largest scale sediment augmentation has been performed in the Nakagawa.

The results show that the developed model is able to simulate the sediment transport process from sediment augmentation. Furthermore, sediment deposition areas of each sediment size class are simulated. The coarse sediment is transported only within $3-4 \mathrm{~km}$. On the other hand, the fine material is transported to the downstream area from $10 \mathrm{~km}$ to $20 \mathrm{~km}$. As a result, bed material from $4 \mathrm{~km}$ becomes finer more than that near the replenished sediment area.

Key Words : sediment augmentation, bed deformation analysis, numerical simulation, non-uniform sediment, rigid bed

\section{1. はじめに}

ダムへの堆砂によって，下流への土砂供給が減少する ことによる下流河川における河床低下，河床材料の粗粒 化などへの対策として，ダムに堆積した土砂の掘削土砂 をダム下流河道へ置土し，洪水時に流下させる土砂還元 の実施事例が近年増加している.

土砂還元を実施する上では，下流河川における治水安 全度の確保と生物の生息環境や物理環境の変化に配慮し つつ, 河床位および河床材料の粒度を回復することが必 要となるために, 置土の流下過程と下流の河床高や粒度 の変化を河床変動解析等により予測する手法の確立が必 要とされているとともに，置土した土砂の洪水時の動態 に関する知見の集積が急務となっている.

実際の置土の流下過程に関する解析事例は，植木ら (2006)による多摩川における事例 ${ }^{1)}$, 㐘池ら(2007)による
矢作ダムにおける事例 ${ }^{2)}$, 佐々木ら(2008)および櫻井 (2008)による三春ダムにおける事例 33 , 4)などがある。これ らの事例では置土地点からの土砂の流出現象を主に扱っ ており, 流出した土砂の流下・堆積による下流河道の変 化の状況を把握するまでには至っていない.これは，現 段階で実施されている土砂還元の多くが試験的な実施に 限られており，下流河道の河床変動を捉えるほどの土砂 量を置土するに至っていないためと考えられる.

置土の形状により土砂の流下量をコントロールする方 法の検討では，置土した土砂の平面形状の変化を予測す るための平面2次元河床変動解析モデルが必要である.

また，下流河道の変化についても，河原や瀬・淵の形状 など平面的な地形および粒度の変化の把握が必要である.

一方で, 土砂還元による変化は長期的かつ広範囲に把 握する必要があり，2次元解析では計算負荷が大きく長 期かつ広範囲の河道を対象に解析を行うのは困難である. 
従って, 本研究では, 図-1に示すように置土地点と置 土による河床位と河床材料の粒度の回復効果の評価地点 は2次元解析，置土地点～評価地点は1次元解析を適用し た解析モデルを構築し，全国でも最大規模の置土を実施 している徳島県・那賀川における事例を対象として，置 土地点からの土砂の流出，下流河道における土砂の流 下・堆積状況の数值シミュレーションを行い，解析モデ ルの再現性について検討寸るとともに，置土した土砂の 洪水時の動態について検討している.

本論文では，これらの研究のうち，1次元河床変動解 析による，置土から流出した土砂が河道を流下寸る過程 の数值シミュレーションについて，那賀川における置土 事例を対象に再現計算を行い，再現性を確認寸るととも に, 解析結果から得られる情報について考察を行った結 果について示す。

\section{2. 解析モデルの構築}

\section{（1）解析モデル}

本研究で用いる一次元河床変動解析には, 将来, 数十 年の長期予測が実施できるように流れの計算に不等流計 算を用いた 1 次元河床変動解析モデル5)を用いた.

解析モデルの基礎式は以下の通りである.

$\frac{d}{d x}\left(\frac{1}{2 g} \cdot \frac{Q^{2}}{A^{2}}\right)+\frac{d H}{d x}+i_{e}=0$

$\frac{\partial A_{z}}{\partial t}+\frac{1}{(1-\lambda)} \cdot\left\{\frac{\partial}{\partial x}\left(\sum_{k}\left(B \cdot q_{B k}\right)\right)+B \cdot \sum_{k}\left(c_{s b c k}-c_{s b k}\right) w_{k}\right\}=0$

$\frac{\partial c_{s s} A}{\partial t}+\frac{\partial c_{s k} Q}{\partial x}=B \cdot\left(c_{s b o k}-c_{s b k}\right) \cdot w_{k}$

ここに, $x$ : 河道流下方向の座標, $t$ : 時刻, $Q$ : 流量, $A$ : 流下断面積, $H$ : 水位, $A_{z}$ : 堆積土砂の断面積, $\lambda$ : 空隙率, $B$ : 河床幅, $\mathrm{g}$ : 重力加速度, $i_{\mathrm{e}}$ : エネルギー勾 配であり，マニング則により評価した。また， $k$ は粒径 階を示寸添え字，（は全粒径の和を示しており，各粒 径階について $w_{k}$ : 沈降速度, $q_{B k}$ : 掃流砂量, $c_{s k}$ : 水深平 均浮遊砂濃度, $c_{\text {sbk }}$ : 河床基準面における浮遊砂濃度, $c_{s b e k}$ : 河床基準面における平衡浮遊砂濃度である.

河床材料の粒度分布は，図-2に示すように鉛直方向に 交換層と堆積層を想定し，以下に示寸粒径階ごとの連続 式(の)，7により交換層における粒径階 $k$ 存在率 $f_{b k}$ を算出し た.

$\partial A_{z} / \partial t \geqq 0$ の場合（河床上昇時）

$$
\frac{\partial f_{b k} A_{b}}{\partial t}+f_{b k} \frac{\partial A_{z}}{\partial t}+\frac{1}{(1-\lambda)}\left\{\frac{\partial\left(B \cdot q_{b k}\right)}{\partial x}+B \cdot\left(c_{s b o k}-c_{s b k}\right) w_{k}\right\}=0
$$

$\partial A_{z} / \partial t<0$ の場合（河床低下時）

$$
\frac{\partial f_{d l k} A_{b}}{\partial t}+f_{b k} \frac{\partial A_{z}}{\partial t}+\frac{1}{(1-\lambda)}\left\{\frac{\partial\left(B \cdot q_{B k}\right)}{\partial x}+B \cdot\left(c_{s b c k}-c_{s b k}\right) w_{k}\right\}=0
$$

交換層厚 $\delta$ は河床材料の最大粒径程度を想定し $25 \mathrm{~cm}$ に 設定し, 各堆積層の厚さ $E_{d} か ゙ 25 \mathrm{~cm}$ を超えると層の数が増 加するように設定した．また、解析対象河道は概ね露岩 していることから，初期の全層厚 $E_{t}$ は基本的に 0 と， 河原などが存在する断面についてはそれらの断面積，川

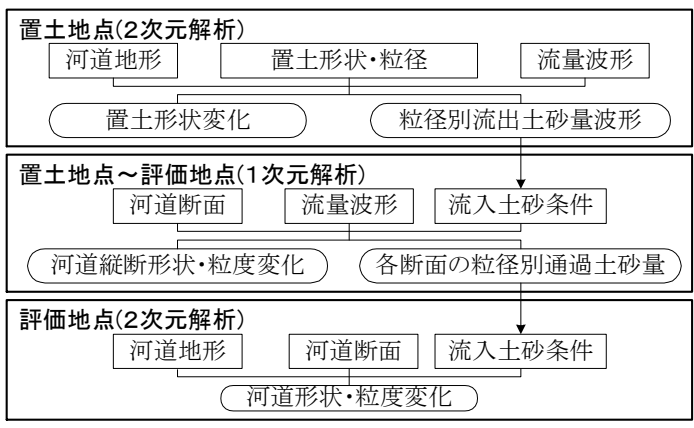

\section{図-1 解析モデルの概念図}

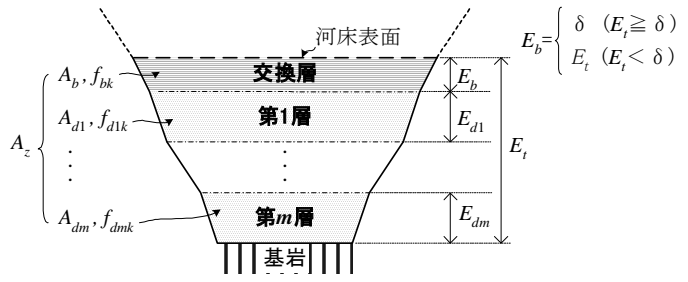

\section{図-2＼cjkstart交換層の概念図}

ロダム貯水池内は堆砂の断面積が，解析モデル上の堆積 断面積に等しくなるように全層厚 $E_{t}$ を与えた.

掃流砂量は，芦田・道上式8)，基準面高さにおける平 衡浮遊砂濃度については，Lane\&Kalinske式”を用い，そ れぞれ式(6)，式(7)に示すように算出した。

$$
\begin{aligned}
& q_{B k}=17 \frac{u_{s e}^{3}}{s g}\left(1-\frac{u_{s c k}}{u_{*}}\right)\left(1-\frac{u_{s c k}^{2}}{u_{*}^{2}}\right) \cdot f_{b k} \cdot r_{b} \\
& c_{s b e k}=5.55 \cdot\left(0.5 \cdot u_{*} / w_{k} \cdot \exp \left(-w_{k} / u_{*}\right)\right)^{1.61} \cdot f_{b k} \cdot r_{b}
\end{aligned}
$$

ここに, $u_{*}$ : 摩擦速度, $u_{*}$ : 限界摩擦速度, $u_{*}$ : 限界摩擦速 度, $s$ :土粒子の水中重量である. また, $r_{b}$ は土砂の堆積厚 $E_{t}$ が減少し, 設定された交換層厚 $\delta$ よりも小さくなった場合に流 砂量を減少させるパラメータであり，以下のように表される ${ }^{10)}$

$$
r_{b}=\left\{\begin{array}{cc}
1 & \left(E_{t} \geqq \delta\right) \\
E_{t} / \delta & \left(E_{t}<\delta\right)
\end{array}\right.
$$

式(6)および式(7)において，右辺に $r_{b}$ を乗じているのは， 従来各粒径の存在率 $f_{b k}$ を乗じるのと同様に, 露岩河床上 の河床材料の存在率の減少による，平衡流砂量および平 衡浮遊砂濃度の減少を評価寸るためであり，移動しない 大粒径として，露岩を扱っていることと同様になる。

置土が必要とされている河川の多くは，供給土砂量の 不足により，河床の一部から岩が露出していることが多 い. 那賀川においても，熟敷地区に代表されるように， 岩が河床から露出している. 従来，このような場での土 砂の伝播は、岩露出域に流れ込んだ土砂が即座に下流の 移動床域に到達するような取り扱いが多くなされていた が，本研究では，岩露出域の土砂の伝播プロセスを表現 するために，上記のようなパラメータを導入した.

\section{3. 解析モデルの実河川への適用}

\section{(1) 解析対象現象の概要}

\section{a）那賀川における置土の概要}

那賀川では, 長安口ダムからの掘削土砂を下流へ置土し ている. 平成3年度から平成18年度までは徳島県により, 年 $2,000 \sim 24,000 \mathrm{~m}^{3}$ の置土が実施されてきた. 平成19年度から 
は国土交通省により実施され, 置土量が増加されている.

平成20年度には55,700 $\mathrm{m}^{3}$ が設置された。しかし，置土 が流下する規模の出水が無く，平成 21 年度に合計 $159,900 \mathrm{~m}^{3}$ の置土が設置された状態で，平成21年8月9日 〜10日に台風9号による出水が生じ, 置土量増加以降, 初めての置土流下となった.

図-3に平成21年台風9号による出水時に、置土が設置さ れていた地点を示す. 長安口ダム下流には, 逆調整池であ り比較的越流頂の低い川口ダムが存在しており, 川口ダム より上流の2地点 (小浜橋上流地点, 桜谷地点), 下流の 2 地 点(川口ダム下流地点, 朝生地点) で置土が実施されている.

平成21年台風9号出水時の置土量は表-1に示す通りで ある. 川口ダムより上流の小浜橋上流地点は $54,700 \mathrm{~m}^{3}$, 川口ダムより下流の朝生地点では $83,100 \mathrm{~m}^{3}$ であり，特に 置土の規模が大きい地点となっている.

平成21年台風9号出水前の各地点の置土の粒度分布を 図-4に示す，那賀川における置土では，長安口ダム下流 に位置する川口ダムの堆砂が増加しないように配慮する ため，川口ダムの上流に置土する土砂の粒度と川口ダム の下流に置土寸る土砂の粒度を変えている。つまり，川 口ダムを通過しにくい大粒径を含む材料Aと，含まない 材料Bに区分し，川口ダム上流には材料Bを置土してい る.このように，日本の多くの河川で見られるように， ダムが連続している河川では，下流側に存在するダムの 機能に配慮し置土の粒径を設定する必要がある.

b）検証対象出水の発生状況

平成21年台風9号による出水は，8月9日〜10日にかけ て発生した。朝生置土地点より $5 \mathrm{~km}$ 下流に位置する和食 流量観測所における出水時の流量(10分間隔)を図-5に示 す. 9日 $18: 30$ に $3,140 \mathrm{~m}^{3} / \mathrm{s} の 1$ 回目のピークが発生し, 10

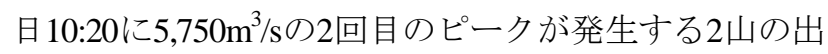
水となっている.

\section{c）置土の流下状況}

台風9号出水後の地形測量より, 表-1に示すように, 約16 万 $\mathrm{m}^{3}$ 設置されていた置土の流下量は約 12 万 $\mathrm{m}^{3}$ であった.

\section{d）下流河道の変化の状況}

流下した置土が下流河道の河床材料, 河床形状, 生物 環境の変化によ゙のような影響を与えるかについては，い まだ十分な知見が得られていない. そこで，那賀川では

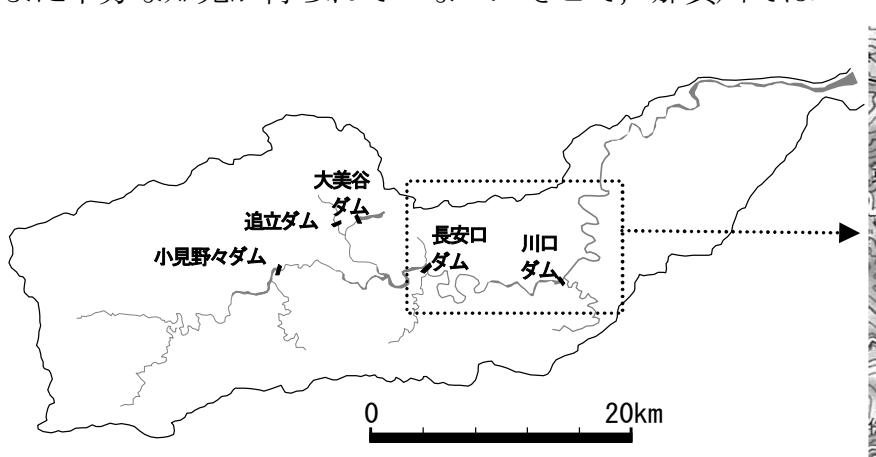

置土によるこれらの変化の状況を確認するモニタリング 調査を実施している.

置土流下による河道の変化は，置土地点から下流へ離 れるほど小さくなるものと考えられる，従って，河道の 変化を確認するためのモニタリング調査地点（以降, 評 価地点）は，図-3に示すように，縦断的に位置を変化さ せた8地点が配置されている，これは，置土量が多い小 浜橋上流地点および朝生地点からの流出土砂の影響の流 下方向の変化を把握するためである.

モニタリング調査項目は表-2に示す通りであり，本検 討ではこの調査から得られる情報を対象とした。

8箇所の評価地点におけるモニタリング調査では, 出

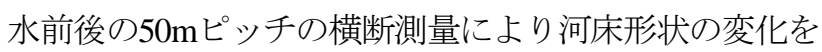
確認するとともに，河床材料マップ作成による河床材料 の平均粒径の変化が確認されている. また, 出水後に顕 著に堆積した場所の土砂を採取して粒度分布を測定し,

\section{表-1 台風9号出水時の置土の設置·残留·流下量}

\begin{tabular}{|c|r|r|r|r|r|}
\hline & $\begin{array}{c}\text { 小浜橋 } \\
\text { 上流 }\end{array}$ & \multicolumn{1}{|c|}{ 桜谷 } & $\begin{array}{c}\text { 川口ダム } \\
\text { 下流 }\end{array}$ & 朝生 & 合計 \\
\hline 設置量 & 54,700 & 3,900 & 18,200 & 83,100 & 159,900 \\
\hline 残留量 & 7,100 & 0 & 6,700 & 26,500 & 40,300 \\
\hline 流下量 & 47,600 & 3,900 & 11,500 & 56,600 & 119,600 \\
\hline 流下率 & $87.0 \%$ & $100.0 \%$ & $63.2 \%$ & $68.1 \%$ & $74.8 \%$ \\
\hline
\end{tabular}
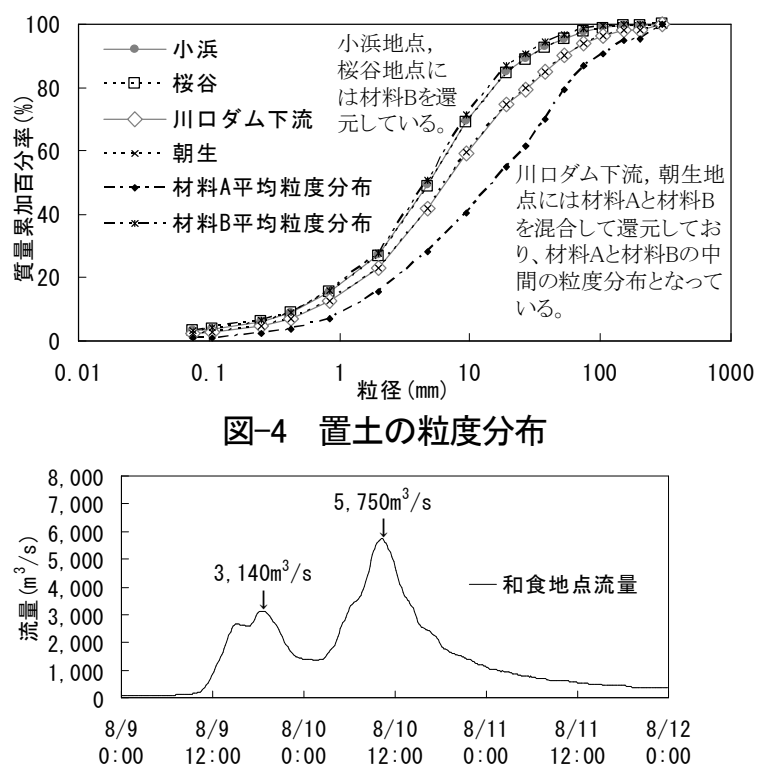

図-5 平成21年台風9号出水時の水位 · 流量

注 : 和食地点流量は, 平成21年の水位·流量曲線が未確定のため, 近年の 大規模出水発生年(平成16年)の水位·流量曲線を用いた推定值である.

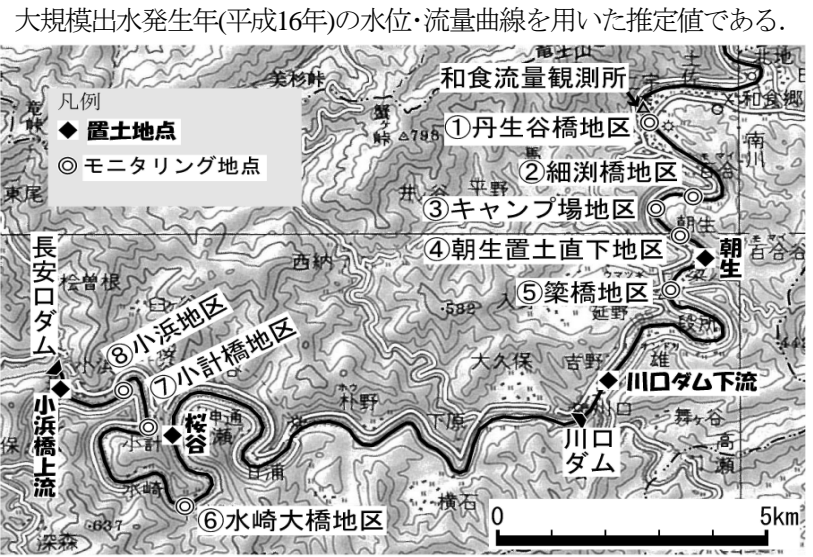

図-3 那賀川における置土地点とモニタリング地点の位置図 
還元土砂の粒度分布との比較から置土による土砂の堆積 であることを確認している.

河床材料マップは図-6に示すように，粒径を7区分す るとともに，材料の混在状況を記録している.

図一泣評価地点において確認された河床材料変化の1例 を示寸.この図に示寸範囲は流下方向に約 $400 \mathrm{~m}$, 横断方 向に約 $50 \mathrm{~m}$ 程度の限られた範囲であるにもかかわわらず, 置 土の堆積のしかたは一様ではなく, 分級された土砂の堆積 箇所が散在している. また，全体的に河床材料は細粒化 しているが，調查地点下流域の方が細粒分の堆積が多い ことがわかる. これは, 後で示寸 1 次元河床変動解析結 果から推察すると, 粗い粒径よりも細かい粒径の方が置 土地点よりも下流域に輸送され，堆積することによるも のと考えられる.

8籄所の評価地点における河道の地形測量による河床変 動量と, 河床材料マップ作成による土砂の堆積状況および 河床材料の変化状況のモニタリング調査結果から確認され た河道の変化状況をまとめると図-8に示すようになる.

図-8に示すように，平成 21 年台風 9 号出水による，小 浜置土地点からの流出土砂の顕著な堆積範囲は小浜地区 〜小計橋地区であり, 朝生置土地点からの流出土砂の顕 著な堆積範囲は朝生置土直下地区〜細㴊橋地区であった。

これらの結果より, 1 出水により河床形状および河床材料 に顕著な変化が確認された範囲は置土地点から約 $3 \mathrm{~km}$ 程 度の範囲であり,これより下流へ置土による顕著な変化が伝 播するためには, 複数回の出水により, 土砂が下流へ移動 するとともに, 継続的な置土が必要と考えられる.

\section{（2）流下土砂移動状況の再現計算}

置土された土砂の流下過程に関する1次元解析は, 置土 地点で実施した平面2次元河床変動解析から得られた粒径 別流出土砂量を置土地点における供給土砂量しして与える とともに, 支川からの流入土砂量を, 支川河道形状と支川河 道の粒度分布をもとにした平衡流砂量により与えた。

置土地点からの流出土砂量は, 土砂還元地点の河道が 露岩していることから, 縦断方向 $20 \mathrm{~m}$ 、横断方向 $5 \mathrm{~m}$ 程度の 河床地形の2次元メッシュデータを固定床とし, その上に置 土高さを図-3の粒度分布の移動床として与え, 一般座標系 のTVDマッコーマック法による平面2次元河床変動解析 ${ }^{11)}$ 行い, 表-3および図-9に示ように置土の流下量および出水 前後の置土形状変化の再現性を確認した上で用いた.

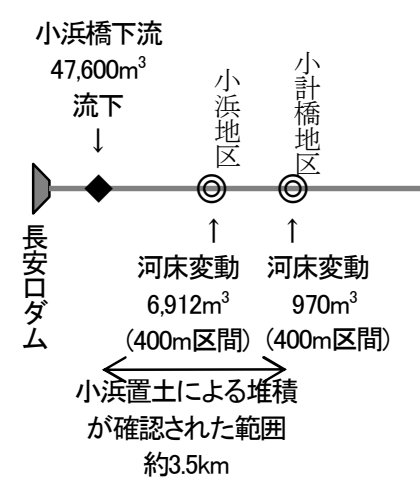

図-8
平衡流砂量を算出する際の支川流量条件および流れ計 算の流量条件は, 川口ダム流入量と和食地点流量の 10 分 間隔の観測值を用い、図-10に示すように流域面積配分で 各時刻の流量を設定した. また, 川口ダム地点に貯水位の 10分間隔観測值を与え, 下流端には等流水深を与えた.

置土による流砂量の変化を抽出寸るため, 置土あり・なし の2通りについて計算を行い, 流砂量の差分から置土による 流砂量および河床変動量の変化を抽出した.

\section{表-2 モニタリング調査項目}

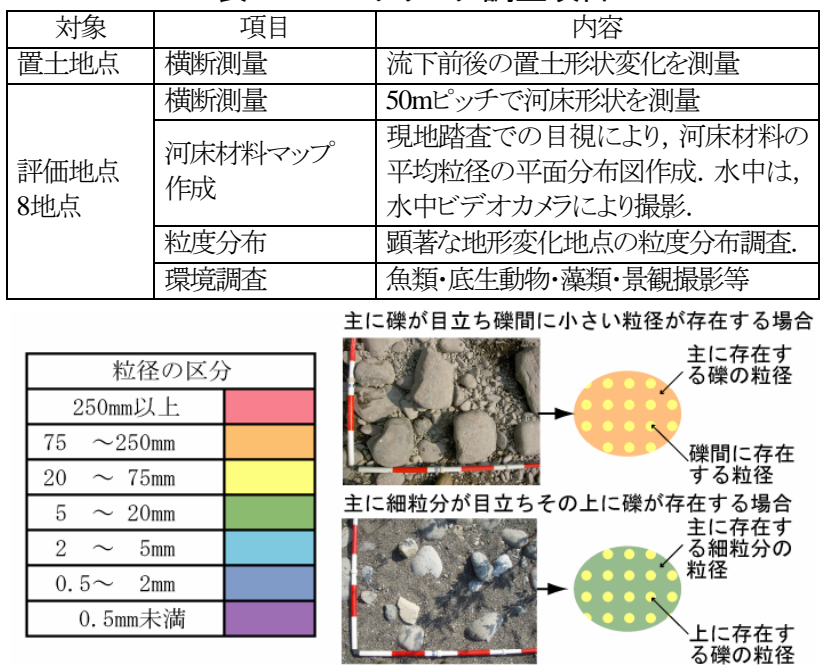

図-6 河床材料の区分と河床材料マップにおける表現方法

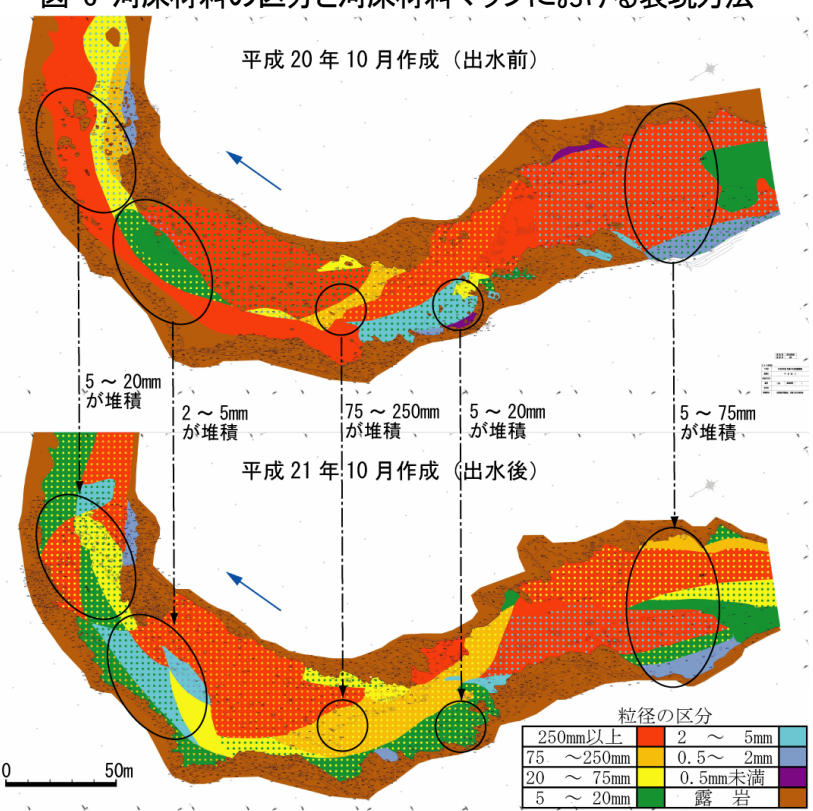

図-7 評価地点において確認された変化の1例（小浜地区）

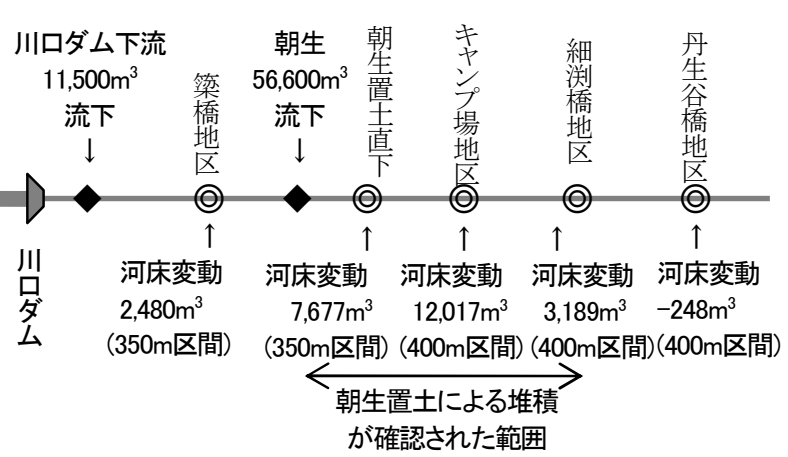




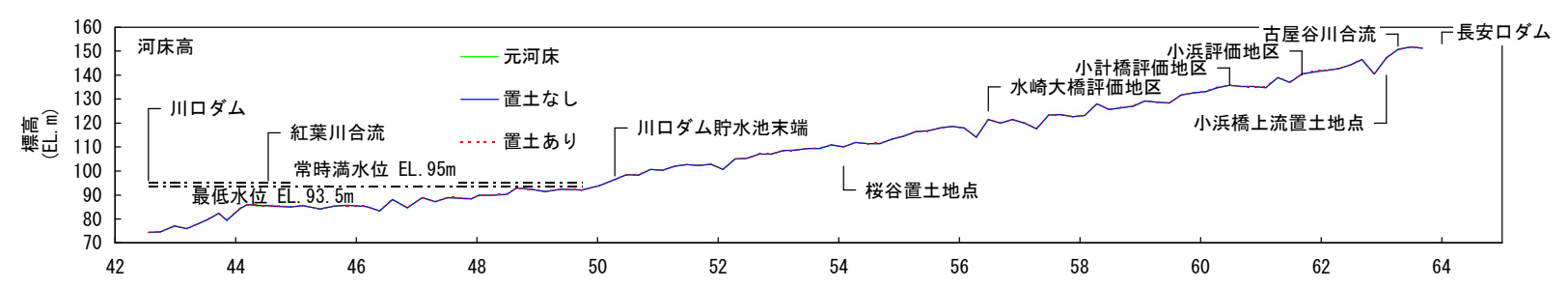

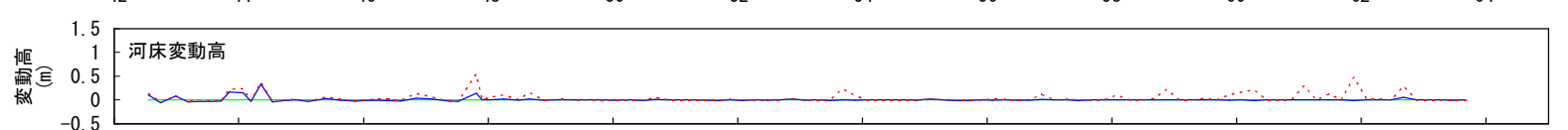

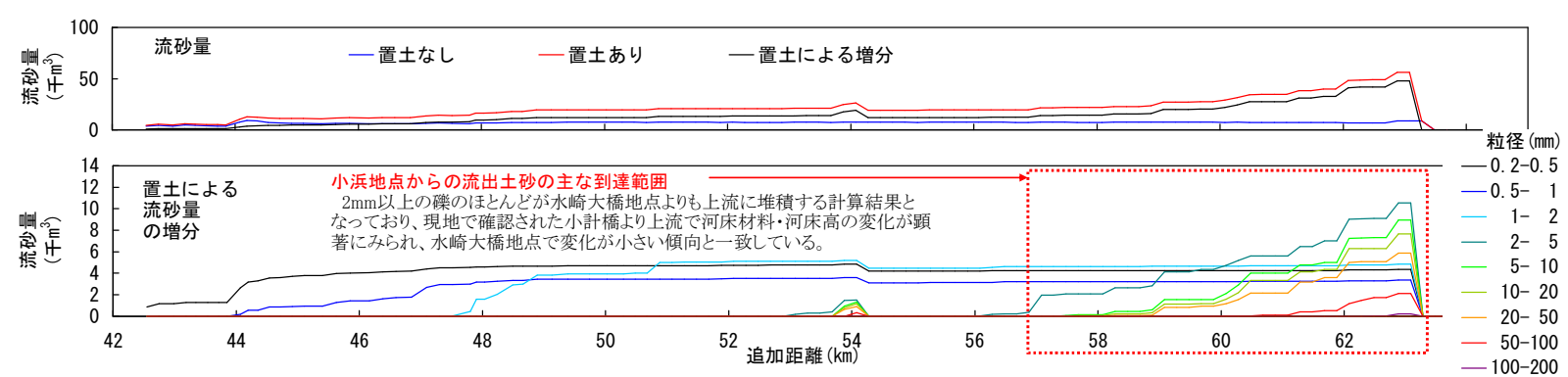

図-11 河床高と流砂量の変化の解析結果(長安ロダム〜川ロダム)

\section{(3) 考察}

解析結果から得られた河床高と流砂量の変化を図-11 および図-12に示す。計算結果による置土の堆積範囲は, 図-8に示したモニタリング調査により土砂の堆積が確認 された範囲と概ね一致する結果となった。

また，測量により把握された評価地点の河床変動量と 解析結果の河床変動量を比較すると図-13に示すように なる．両者の河床変動量に差が見られるものの、評価地 区ごとの河床変動の多䓖の傾向がほぼ再現される結果と なった。しかし，当然ながら実際の土砂の堆積状況は横 断方向の偏りがあり, 図-7に示すように横断方向の分級が 顕著である. 1次元河床変動解析では, このような現象の再 現が出来ないこと, 岩塊などの存在による河幅の局所的な 変化の影響が再現できないことなどの限界がある点は注意 が必要である.

また、本研究の対象河道は，図-7に示したように粒径 の大きい礫分で構成されている.このような石礫河川では, 巨石等による静的な河床安定機構により, 砂碟河川で使わ れてきた従来の動的平衡を想定した流砂量式や浮遊砂濃 度式の適用に問題点があることから, 福岡・長田らは河床材 料の静的平衡を組み込んだ解析モデルを提案している ${ }^{12)}$. また，関根らは従来の浮遊砂浮上量の推定式を㗂床に適 用する際の問題を指摘し，礫間に細粒土砂が充填される 機構を考慮して浮遊砂浮上量を求めるモデルを提案して いる ${ }^{13)}$.

本研究で適用した解析モデルは、長期に亘る置土によ る影響の将来予測に用いることを前提としており，汎用 性と解析に関寸る負荷の軽減を重視し，これらに示され た点は考慮せず，従来広く用いられている平衡流砂量、 平衡浮遊砂濃度により解析している。

以上に示したように，1次元解析であること，掃流砂 の非平衡性や礫間からの詳細な浮遊砂の浮上機構を考慮 したモデルとなっていないことによる解析精度の限界は
表-3 置土流下量実績と計算結果の比較 (単位: $\mathrm{m}^{3}$ )

\begin{tabular}{|c|r|r|r|r|}
\hline & 小浜橋上流 & \multicolumn{1}{|c|}{ 桜谷 } & 川口多不流 & \multicolumn{1}{c|}{ 朝生 } \\
\hline 実績流下量 & 47,600 & 3,900 & 11,500 & 56,600 \\
\hline 計算結果 & 48,000 & 3,600 & 10,900 & 56,300 \\
\hline
\end{tabular}
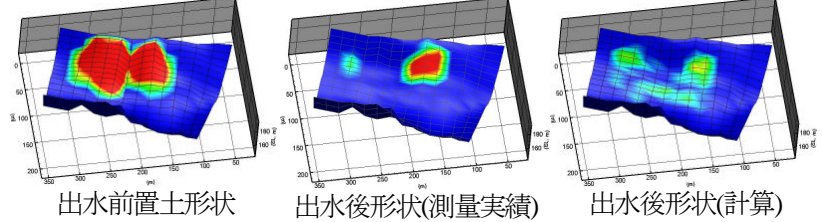

凡例 : 土砂堆積深さ

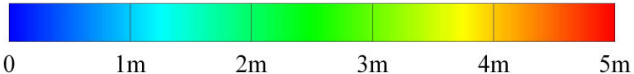

図-9 置土形状変化実績と計算結果の比較例(小浜橋上流)

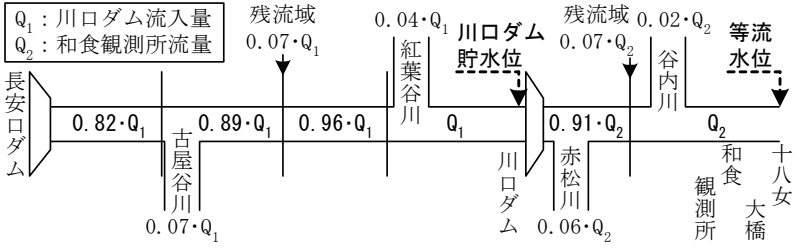

図-10 1次元河床変動解析に用いた流量配分

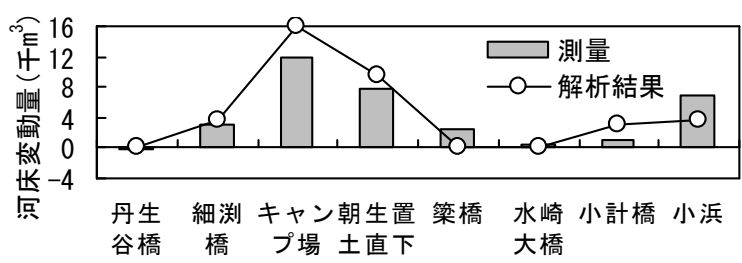

図-13 評価地区河床変動量の測量結果と解析結果の比較

あるものの，置土された土砂の到達範囲については概ね 再現することが可能であった。

図-9および図-10に示した置土による流砂量の増分から は, 粒径別ごとに土砂の到達範囲が大きく異なっていること が確認できる. 50mm〜 100mmの礫分は置土地点から 1 $3 \mathrm{~km}$ 下流の範囲で堆積する結果となっている. また, $2 \mathrm{~mm} 以$ 上の礫分は置土地点功 $3 〜 5 \mathrm{~km}$ の範囲で堆積している.こ のように, 粒径が大きく, 移動しにくい碩分により河床位を早 

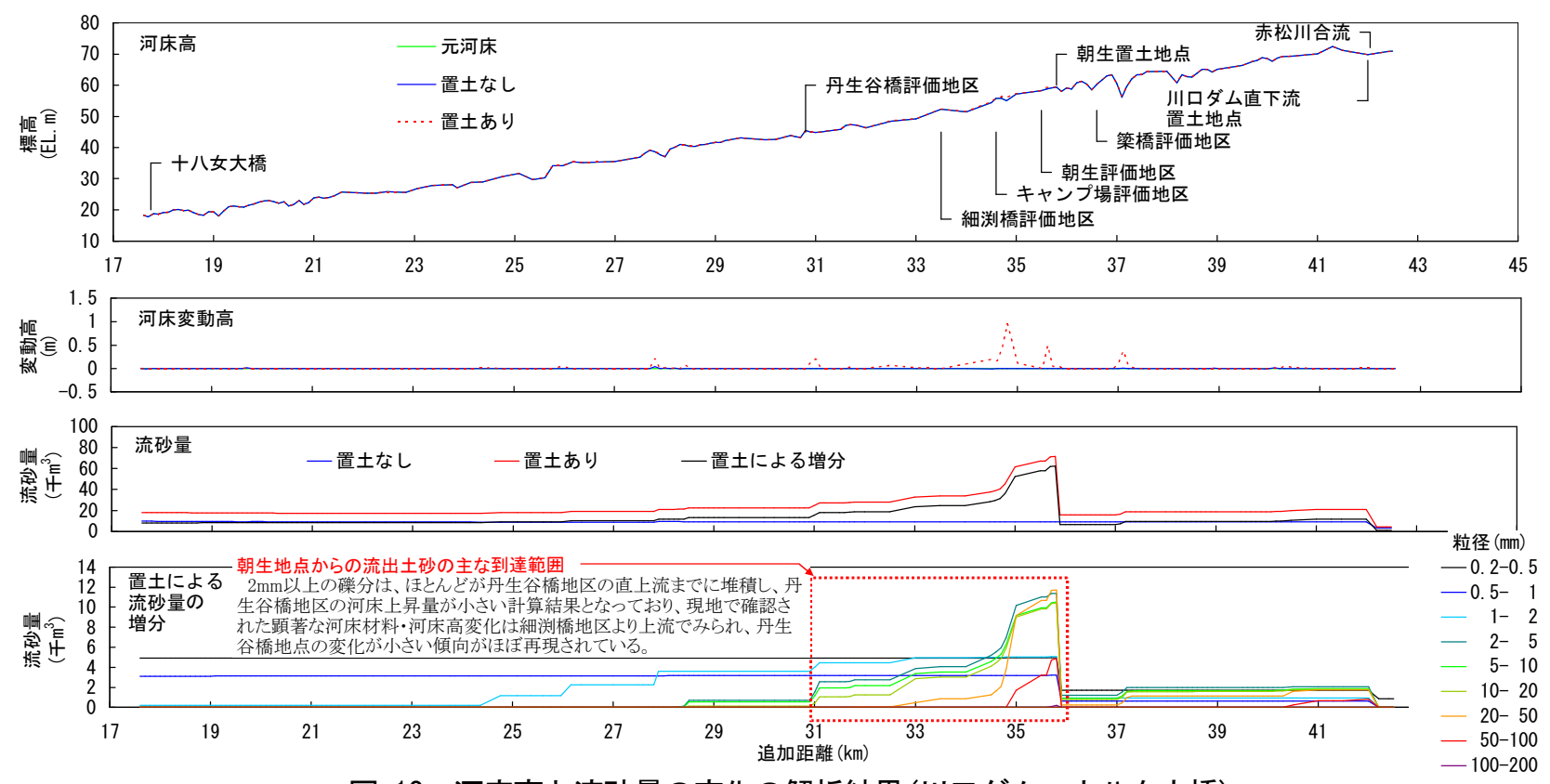

図-12 河床高と流砂量の変化の解析結果 (川口ダム〜 八女大橋)

期に回復するためには，目的とする地点の直上流域に置土 する必要があるものと考えられる. $2 \mathrm{~mm}$ 未満の砂分は移動 距離が長く, 小浜地点から流出したものは川口ダム貯水池 まで到達し, 朝生地点功流出したものは今回計算対象とし た範囲よりも下流まで到達する結果となっている.

以上に示したような粒径別の到達範囲の違いから, 河床 位の上昇は置土地点直下流部において顕著に表れている が, 河床材料の細粒化はさらに下流でも発生し得るものと考 えられる. また, これらの結果より, 置土を実施するときは, その量だけでなく, どのような粒度の土砂を用いて置土を実 施するかといら点が非常に重要であることがわかる.さらに, 置土が下流の河床形状や河床材料の粒度の変化を通して 生物の生息場に与える影響を検討寸る場合は, 河床材料を 混合砂しして扱わなければ評価が難しいことが予想される。

\section{4.おわりに}

本論文では, 置土から流出した土砂が河道を流下寸る過 程を1次元河床変動解析によりシミュレーションするモデル の構築を行い, 実河川における置土の事例を対象とした再 現計算により, モデルによる再現性を確認寸るとともに, 解 析結果から得られる情報について考察を行った。

本論文における1次元河床変動解析を用いた再現計算 により，実河川の置土による流出土砂の堆積特性を概ね 再現することができた．また，粒径別の土砂の到達範囲 の違いについて明らかにできることから，置土による下 流河道の河床位や河床材料の粒度分布の変化の発生位置 や堆積粒径を予測し、置土計画を立案するための重要な ツールになると考えられる.

ただし，本検討で再現対象とした置土地点下流河道の河 床変動状況は, 8箇所のモニタリング地点におけるものであ り, 河道全体の土砂収支について確認できていないため, より詳細なデータ収集を行った上で, 解析モデルの粒径別
土砂収支の再現状況を確認寸ることが今後の課題である.

\section{参考文献}

1) 植木真生, 福島雅紀, 山下武宣: 河道掘削及び砂礫の敷設供給 に対する河床の応答, 河川技術論文集, 第12巻, pp.415-420, 2006

2) 菊池英明, 小出武文, 小林信昭, 末次忠司, 岡野真久:長期排 砂対策を考慮したダム下流土砂還元試験と影響調查に関する 提案, 河川技術論文集, 第13巻, pp.69-74, 2007

3) 佐々木崇憲, 櫻井寿之, 箱石憲昭: 三春ダム直下流における置 土侵食の平面2次元河床変動解析, 土木学会第63回年次学術 講演会講演概要集, pp.253-254, 2008

4) 櫻井寿之: 置土の侵食過程と流送過程の数值計算, 置土シンポ ジウム, pp.59-66, 2008

5) 道上正規, 藤田正治, 前田真吾: 非平衡浮遊砂を考慮した急勾 配水路における貯水池堆砂の計算法, 水工学論文集, 第34巻, pp.367-372, 1990

6) 平野宗夫: Armoringを伴う河床低下について, 土木学会論文集, 第195号, pp.55-65, 1971

7) 櫻井寿之, 鎌田昌行, 柏井条介, 鈴木伴征: 混合粒径河床変動 モデルによる貯水池堆砂·排砂現象の再現, ダム工学, Vol.16, No.1,pp.30-40, 2006

8) 芦田和男, 道上正規:移動床流れの抵抗と掃流砂量に関寸る基 礎的研究, 土木学会論文報告集, 第206巻, pp.59-69, 1972

9) Lane, E. W. and Kalinske, A. A. : Engineering calculation of suspended sediment, Trans. A.G.U., 22, 1941

10) Hiroshi Takebayashi, Shinji Egashira and Haisheng Jin:Effect of sediment sorting on geomorphologic characteristics of alternate bars, Proc. 27th Congress of IAHR, Theme B, pp. 1433-1438, 1997.

11) 竹林洋史: 河川中・下流域の河道地形, ながれ, 第24巻, 第1 号, pp. 27-36, 2005.

12) 長田健吾, 福岡捷二:石磻河川の土砂移動機構に着目した1次 元河床変動解析法の開発, 水工学論文集, 第52巻, pp.625-630, 2008

13）関根正人:砅・シルト充填河床モデルを用いた礫河道の 準二次元河床変動解析, 水工学論文集, 第51巻, pp.973-978 2007

(2010. 9. 30受付) 